\title{
PANDANGAN MUI NTB TERHADAP ATURAN PENDEWASAAN USIA PERNIKAHAN DI NUSA TENGGARA BARAT
}

\author{
Enik Citrawati ${ }^{1}$ \\ Prodi Magister AS UIN Mataram \\ Email: enikcitrawati187@gmail.com
}

\begin{abstract}
Abstrak: Nusa Tenggara Barat merupakan daerah dengan tingkat kasus pernikahan usia dini tertinggi di Indonesia. Kondisi ini mendapatkan perhatian pemerintah provinsi NTB, karena dikhawatirkan akan mengganggu proses pembangunan kualitas sumberdaya manusia NTB. Bentuk perhatian pemerintah tersebut dituangkan dengan mengeluarkan aturan tentang pendewasaan usia pernikahan bagi masyarakat. Penelitian ini bermaksud memahami pandangan MUI NTB terkait dengan intervensi pemerintah yang mengatur batas usia pernikahan tersebut, karena dalam Islam, tidak ada ketentuan tentang batas usia pernikahan, dan jika terjadi kasus yang tidak ada ketentuan hukumnya dalam Islam, maka MUI merupakan lembaga yang memiliki otoritas untuk memberikan fatwa hukumnya. Penelitian ini menggunakan pendekatan kualitatif. Hasil penelitian ini mengungkapkan bahwa MUI sependapat dengan apa yang dilakukan pemerintah yang mengatur tentang pendewasaan usia pernikahan bagi masyarakat, mengingat mudharat yang diakibatkan dari perilaku masyarakat yang melakukan pernikahan usia dini, dan alasan pemerintah mengeluarkan aturan tersebut untuk kemaslahatan masyarakat.
\end{abstract}

Kata Kunci: Pernikahan, MUI, Pendesaan Usia, Hukum Islam

\section{PENDAHULUAN}

Saat ini, perilaku pernikahan usia dini sedang mendapatkan perhatian pemerintah, karena jumlahnya yang cukup tinggi. Menurut Badan Pusat Statistik (BPS) Indonesia, bahwa pada tahun 2015, sebanyak 1.000 anak perempuan Indonesia menikah setiap harinya, dan menjadi yang paling banyak di Asia Fasifik. Kondisi ini, menurut Subandi Sardjoko (Deputi Bidang Pembangunan Masyarakat dan 
Kebudayaan dari Badan Pembangunan Nasional Indonesia), apabila dibiarkan terus terjadi, maka akan mengganggu rencana pemerintah dalam melakukan pembangunan yang berkelanjutan (Sustainable Development Goals). Bahkan dapat melahirkan kondisi generasi bangsa yang tidak produktif dalam upaya membangun bangsa yang lebih maju pada masa yang akan datang. ${ }^{2}$

Fenomena maraknya perilaku masyarakat yang melakukan pernikahan dini ini juga terjadi di NTB. Bahkan kondisinya menunjukkan trend cukup tinggi, karena menurut survey nasional, NTB berada pada urutan tertinggi. ${ }^{3}$ Menurut Kepala Badan Pemberdayaan Perempuan Perlindungan Anak dan Keluarga Berencana (BP3AKB), setengah dari penduduk NTB melakukan pernikahan dini. Berdasarkan hasil penelitian BP3AKB, tahun 2014, persentase pernikahan dini di NTB mencapai $51,8 \%$ dan tahun 2015 mencapai 34,9\%. Jumlah remaja sebagai pelaku pernikahan usia dini di NTB sepertiga dari total penduduk NTB yang berjumlah 4,8 juta. ${ }^{4}$

Sedangkan rata-rata tingkat pendidikan mereka yang melakukan pernikahan dini ini adalah remaja tamatan SMP-SMA, sehingga kondisi pendidikan yang masih rendah juga ditengarai ikut menjadi salah satu faktor yang mempengaruhi kasus pernikahan dini di NTB. ${ }^{5}$ Sedangkan di sisi lain, menurut Kepala DP3KB NTB, bahwa efek sosial dari kasus pernikahan dini yang masih marak terjadi dalam masyarakat telah memicu tingginya tingkat angka perceraian di NTB. ${ }^{6}$ Memperhatikan, fenomena praktik hukum keluarga Islam yang implikasinya kurang baik bagi kemaslahatan hiduap masyarakat NTB, yang diperlihatkan dalam kasus pernikahan usia dini, akhirnya mendorong Pemerintah Provinsi NTB untuk melakukan upaya peningkatan usia pernikahan menjadi minimal 21 tahun, sebagaimana tertuang dalam Surat Edaran (SE) Gubernur No.150/1138/Kum/2014 tentang Pendewasaan Usia Pernikahan.

Adanya intervensi pemerintah daerah terhadap praktik pernikahan masyarakat Islam melalui kebijakan pembatasan usia pernikahan, memiliki relevansi untuk dikaji secara hukum Islam, karena sebagaimana diketahui bahwa Islam memang tidak menjelaskan secara explisit tentang batasan usia minimal diperbolehkannya melangsungkan praktik pernikahan bagi umat Islam. Kajian penelitian ini dimaksudkan untuk memahami perspektif ulama yang tergabung dalam organisasi Majelis Ulama Indonesia yang berkedudukan di Provinsi NTB, karena lembaga ini memiliki otoritas untuk menetapkan keputusan Hukum Islam yang tidak tertuang

2 Suhadi, "Pernikahan Dini", 169.

3 Sirtullaili, “Setengah Warga NTB Merarik Kodek,” Lombok Post, 27 Maret 2015.

4 BP3AKB, "Data Statistik Pernikahan Dini NTB," Dokumentasi (Mataram: BP3AKB Provinsi Nusa Tenggara Barat, 2015), 1 .

5 Fitriani Agustina, "Pernikahan Dini Picu Kemiskinan NTB," Suara NTB, 9 Januari 2017.

6 Sirtullaiali, “Sehari 40 Pasutri Di Ambang Perceraian,” Lombok Post, 4 November 2016. 
dalam sumber-sumber pokok ajaran Islam, dalam rangka memberikan solusi hukum Islam terkait dengan masalah hukum Islam dalam kehidupan masyarakat.

\section{Pernikahan Anak}

Perilaku pernikahan usia dini yang terjadi dalam kehidupan masyarakat Nusa Tenggara Barat, saat ini sedang mendapatkan perhatian pemerintah, karena jumlahnya yang cukup tinggi, dan efeknya dianggap tidak baik bagi kelangsungan rumah tangga para pasangan tersebut. Fenomena kasus ini tidak selalu disebabkan oleh kesulitan ekonomi atau kemiskinan masyarakat, namun juga disebabkan tingkat pendidikan yang rendah dan masih adanya budaya masyarakat yang menganggap bahwa pernikahan usia anak itu merupakan hal yang lumrah, serta tidak ada larangan dalam agama. Menurut kajian BKKBN NTB, terjadinya pada praktik pernikahan yang dilakukan masyarakat yang masih dalam kategori usia anak-anak di NTB, karena dipicu beberapa faktor, di antaranya adalah:

1. Pergaulan. Perilaku pergaulan bebas remaja yang berujung pada penyimpangan seksual yang dilakukan para remaja yang menyebabkan terjadinya kehamilan yang tidak dikehendaki.

2. Keluarga. Rendahnya pengetahuan masyarakat, terutama remaja tentang kesehatan reproduksi akibat rendahnya tingkat pendidikan orangtua.

3. Hukum. Lemahnya penegakan hukum terhadap para pelaku yang terlibat dalam praktik pernikahan usia dini, meskipun sudah ada ketentuan yang ditetapkan dalam peraturan perundang-undangan tentang usia pernikahan.

4. Adat-istiadat. Orang tua di desa desa pada umumnya ingin cepat-cepat mengawinkan anak gadisnya karena takut akan menjadi perawan tua.

5. Ekonomi. Seseorang gadis yang telah kawin berarti lepaslah tanggung jawab orang tua terhadap anaknya, karena sudah menjadi tanggungjawab suaminya, dengan demikian akan mengurangi beban ekonomi orang tuanya.

6. Sosial budaya. Pengaruh sosial budaya baik melalui film, radio, TV, dan teknologi informasi lainnya serta pergaulan muda mudi atau remaja yang lebih bebas dapat mempercepat pematangan jiwa para remaja tersebut. Kematangan jiwa ini akan mempercepat perkawinan, karena mereka sudah tahu tentang kehidupan seksualitas terhadap dirinya.

Sedangkan menurut Kepala BP3AKB, akibat yang ditimbulkan dari perilaku masyarakat yang masih banyak melangsungkan pernikahan pada usia yang masih

7 Nurhayati, "Pendewasaan Usia Pernikahan Menuju Genre 2025". Makalah, disampaikan dalam Kegiatan Desa Binaan UIN Mataram di Desa Sigerongan, 28 Agustus 2017. 
tergolong anak-anak di NTB, banyak terjadi kasus kekerasan dalam rumah tangga. Berikut pernyataannya dalam wawancara dengan peneliti:

"Kita sangat prihatin dengan kondisi masyarakat yang masih banyak melakukan nikah pada usia yang tergolong anak-anak. Salah satu persoalan yang sering kita temui dalam kehidupan rumah tangga para pasangan muda suami-istri di NTB ini adalah kekerasan dalam rumah tangga mereka. Hal ini terjadi karena mereka tidak cukup matang dalam berpikir dan bertindak ketika memiliki persoalan dengan pasangannya masing-masing, seperti jika pasangan mereka melakukan kesalahan, terutama dari pihak perempuan, seringkali pihak suami melakukan pemukulan atau mencaci maki istrinya dengan kata yang tidak baik (menyumpak), dan sementara pihak istri hanya bisa menangis mendapatkan perlakuan kasar dari suaminya".

Pernyataan Kepala DP3KB NTB di atas juga sejalan dengan data tentang angka kekerasan pada anak dan perempuan yang telah rekapitulasi oleh Seksi Pemberdayaan Perempuan dan Anak DP3KB NTB, yang untuk kasus di daerah NTB, jumlahnya cukup memprihatinkan, dimana bentuk-bentuk kasus kekerasannya yaitu, kekerasan seksual (168 kasus), kekarasan fisik (815 kasus), kekerasan psikis (102 kasus), penelantaran (32 kasus), perdagangan (2 kasus), eksploitasi (32 kasus). Adapun untuk kondisi anak, yaitu; anak balita terlantar (2.563 anak), anak terlantar (120.596 anak), anak nakal (10.405 anak), anak jalanan (30.806 anak). ${ }^{9}$

Selanjutnya, menurut Kepala BKKBN NTB, pernikahan usia anak di NTB juga berdampak pada rendahnya tingkat pendidikan masyarakat. Bagi anak yang telah menikah dipastikan tidak akan melanjutkan sekolahnya, terutama bagi anak yang terpaksa kawin karena Kehamilan Tidak Dikehendaki (KTD), karena terkadang mereka diusir dari rumah orang tuanya, dan dikeluarkan dari sekolahnya. Selain itu, cukup banyak perempuan yang nikah usia anak yang tidak mampu mengakses pendidikan, baik formal maupun non-formal, kerena kesibukan mengurus ruma tangganya, sehingga menjadi buta aksara serta buta pengetahuan. ${ }^{10}$

Pernyataan yang sama juga dikemukakan Direktur PKBI NTB, Satyawati, bahwa pernikahan usia anak di NTB telah menimbulkan masalah bagi kesehatan perempuan. Sekitar 100 orang perempuan nikah usia anak yang ditangani pada tahun 2013, terdeteksi 90\% mereka menderita Infeksi Menular Seksual. Kondisi ini juga

8 Hartina (Kepala DP3KB NTB), Wawancara, 24 Maret 2018.

9 DP3KB, Bunga Rampai, 25.

10 BKKBN NTB, "Rapat Koordinasi Revitalisasi Fungsi Keluarga Antara BKKBN Pusat Dengan Mitra”, dalam Suara NTB, Kamis 29 Maret 2018. 
cenderung mengalami peningkatan setiap tahunnya. Hal yang sama juga dikemukakan Staf Ahli Bidang Agama KPPPA, Siti Khadijah Nasution, saat lokakarya di NTB, bahwa pernikahan usia anak akan berdampak pada tumbuh-kembangnya anak yang tidak terpenuhi, karena mempengaruhi kesehatan fisik, seperti organ reproduksi belum sempurna, sehingga rentan berhadapan dengan resiko kematian ibu dan bayinya. ${ }^{11}$

Di samping itu, pernikahan usia anak juga telah menyebabkan lahirnya lingkaran kemiskinan baru di lingkungan keluarganya. Anak-anak yang menikah di usia dini dapat dipastikan tidak akan melanjutnya sekolahnya, sehingga akan mampu bersaing dalam memperoleh pendapaan yang layak untuk pemenuhan kebutuhan keluarga yang layak. Kondisi ini akhirnya akan berdampak terhadap proses pembangunan di NTB, karena komponen indeks pembangunan diukur dari indikator pendidikan, kesehatan, dan ekonomi. Hasil kajian PSKK menunjukkan bahwa setelah menikah, pasangan usia anak masih menjadi tanggung orang tuanya, jumlahnya mencapai di atas 60\%. Hal ini menjelaskan kondisi yang terbalik dengan harapan pasangan pernikahan usia anak, yang mana, keinginan mereka untuk menikah secepatnya, terutama bagi perempuan, karena alasan ingin mengurangi beban hidup atau tanggungan kebutuhan ekonomi yang menjadi beban orang tuanya. ${ }^{12}$

Berbagai efek negatif yang dialami pasangan pernikahan usia dini di NTB tersebut di atas, mendorong Gubernur NTB mengeluarkan kebijakan pembatasan usia minimal bagi masyarakat NTB sebagai syarat diberikan izin untuk melangsungkan pernikahan, yaitu minimal telah mencapai usia 21 tahun, baik bagi laki-laki maupun perempuan, sebagaimana yang tertuang dalam Surat Edaran Gubernur NTB No.150/1138/Kum/2014 Tentang Pendewasaan Usia Pernikahan. ${ }^{13}$ Adanya intervensi pemerintah terhadap praktik hukum keluarga Islam dalam kehidupan masyarakat NTB tentu harus diperkuat dengan landasan hukum Islam, agar apa yang menjadi maksud dan tujuan kebijakan tersebut tidak mendapatkan penentangan masyarakat, khususnya tidak dianggap bertentangan dengan nilai-nilai ajaran agama, karena dalam kehidupan masyarakat NTB, hukum Islam merupakan landasan utama yang mewarnai dan mengendalikan perilaku kehidupannya.

Salah satu lembaga yang memiliki otoritas untuk menanggapi adanya intervensi pemerintah terhadap praktik hukum keluarga Islam berdasarkan perspektif hukum Islam di NTB adalah MUI NTB, karena keberadaan lembaga ini adalah sebagai wadah silaturrahim dan musyawarah bagi para ulama, zu'ama, dan cendekiawan muslim

11 DP3KB, Bunga Rampai, 16.

12 BKKBN, Desiminasi Hasil Penelitian Kependudukan, 12 Desember 2017.

13 Lihat, Point-Point Isi Surat Edaran Gubernur NTB No.150/1138/Kum/2014 Tentang Pendewasaan Usia Pernikahan. 2 Juni 2014. 
Indonesia yang bersifat independent untuk membicarakan permasalahan umat yang bersifat keagamaan dan kemasyarakatan, dengan visinya "Tercipta kondisi kehidupan kemasyarakatan, kebangsaan, dan kenegaraan yang religius, dinamis, produktif, dan kompetitif sebagai hasil penggalangan potensi dan partisipasi umat Islam melalui aktualisasi peran ulama, zu'ama, dan cendekiawan muslim untuk kemajuan umat Islam (i₹zul Islam wal muslimin) guna terwujudnya Islam yang penuh rahmat di tengah kehidupan umat manusia masyarakat ibukota khususnya". ${ }^{14}$

Adapun misi yang dijalankan MUI NTB yaitu menggerakkan kepemimpinan dan kelembagaan umat secara efektif, sehingga mampu mengarahkan dan membina umat Islam dalam menanamkan dan memupuk aqidah islamiyah, dan menjadikan ulama sebagai panutan dalam mengembangkan akhlaq karimah untuk terwujudnya masyarakat yang khaira ummat. Tujuan kehadiran MUI NTB diharapkan dapat berfungsi menggerakkan kepemimpinan dan kelembagaan umat secara dinamis dan efektif, sehingga mampu mengarahkan dan membina umat Islam dalam menanamkan dan memupuk aqidah islamiyah, membimbing umat dalam menjalankan mu'amalah, dan juga menjadikan panutan dalam mengembangkan akhlaq karimah untuk mewujudkan masyarakat yang aman, damai, adil dan makmur rohaniah dan jasmaniah yang diridhoi Allah SWT. ${ }^{15}$

Sedangkan untuk mencapai visi, menjalankan misi, dan mewujudkan tujuannya, MUI NTB membuat sejumlah komisi sebagai perangkat organisasi yang bertugas dan berfungsi untuk menelaah, membahas, merumuskan, dan menyampaikan usulusul kepada Dewan Pimpinan sesuai bidang masing-masing komisi, yang terdiri dari komisi-komisi sebagai berikut:

1. Komisi Fatwa: Memberikan fatwa, bimbingan, dan nasihat terhadap masalahmasalah keagamaan sebagai pedoman dan pertimbangan hukum, bagi pemerintah maupun masyarakat.

2. Komisi Pendidikan dan Kaderisasi: Mengembangkan kualitas materi pendidikan agama Islam, yang mampu menumbuhkan kesadaran setiap individu muslim akan fungsinya, baik sebagai hamba Allah maupun khalifah Allah SWT di muka bumi, sesuai perkembangan ilmu pengetahuan dan teknologi.

3. Komisi Pengkajian dan Penelitian: Melakukan kajian terhadap masalah keagamaan, sosial, politik, ekonomi, pendidikan, serta memberikan kontribusi pemikiran yang realistis dan konstruktif kepada pemerintah dan masyarakat dalam memecahkan berbagai problematika dengan berdasarkan al-Qur'an dan al-Sunnah.

14 MUI NTB, Dokumentasi, Profil MUI NTB 2018.

15 MUI NTB, Dokumentasi, Profil MUI NTB 2018. 
4. Komisi Ukhuwah Islamiyah: Memberikan pemahaman dan pengalaman konsep ukhuwah islamiyah secara utuh, kongkrit, dan realistik menuju terciptanya masyarakat yang marhamah.

5. Komisi Dakwah: Mengembangkan strategi dakwah yang efektif dan efisien agar tugas amr ma'ruf nahi munkar dapat behasil secara optimal dengan tetap mengacu pada wasail da'wah.

6. Komisi Pemberdayaan Ekonomi Umat: Meningkatkan dan memberikan kontribusi positif kepada masyarakat, guna mengatasi problematika ekonomi umat di tengah persaingan ekonomi global, sehingga tercipta ekonomi Islam yang mandiri.

7. Komisi Pemberdayaan Perempuan dan Remaja: Memberikan pelayanan dan menjadi fasilitator permasalahan perempuan, keluarga, dan remaja dengan memberikan penyuluhan dan pemahaman secara kekeluargaan.

8. Komisi Informasi dan Komunikasi: Memberikan informasi kepada masyarakat tentang hasil-hasil fatwa MUI, tausiyah, dakwah, dan arahan dalam bentuk cetak maupun elektronik.

9. Komisi Pengembangan Seni Budaya Islam: Menjadi fasilitator dalam mensyiarkan nilai-nilai seni dan budaya Islam demi terciptanya syi'ar Islam yang rahmatal lil alamin. ${ }^{16}$

Akan tetapi, lahirnya kebijakan pendewasaan usia pernikahan yang diberlakukan pemerintah Provinsi NTB, tanpa keterlibatan MUI NTB, karena MUI NTB tidak mengetahui tentang keberadaan kebijakan tersebut. Namun, menurut pandangan MUI NTB, kebijakan pembatasan usia pernikahan yang dikeluarkan Gubernur NTB tersebut, tidak ada salahnya, jika memang ada dasarnya yang kuat, seperti pernikahan pada usia anak ternyata akan memiliki dampak negatif (mudlarat) yang lebih besar daripada manfaatnya. Dengan kata lain, menurut Ketua Komisi Fatwa MUI NTB, bahwa kalau memang tujuannya untuk kemaslahatan umat, dasarnya juga realistis ilmiah, dan sifatnya urgen untuk memecahkan masalah yang terjadi dalam kehidupan masyarakat, MUI tidak mempermasalahkan tentang adanya intervensi pemerintah yang mengatur batas usia yang dibolehkan menikah untuk pertama kalinya bagi masyarakat, dan hal itu tidak bertentangan dengan hukum Islam. Berikut pernyataannya kepada peneliti:

"Dalam kehidupan berbangsa dan bernegara, memang kita harus patuhi apa yang menjadi ketentuan yang telah dibuat pemerintah atau negara. Jadi terkait dengan kebijakan pendewasaan usia pernikahan di NTB yang ditetapkan

16 MUI NTB, Dokumentasi, Profil MUI NTB 2018. 
melalui SE Gubernur, MUI menganggap tidak masalah, jika ada alasan yang mengharuskannya dilakukan hal itu oleh pemerintah, dan tujuannya untuk kebaikan hidup masyarakat. Islam juga mengajarkan kepada kita untuk taat kepada pemimpin selama mengajak kita kepada kebaikan dan tidak bertentangan dengan ajaran Islam. MUI tentu mendukung apa yang dilakukan pemerintah, meskipun hal itu terkait dengan praktik hukum keluarga Islam, yang semestinya menjadi tugas MUI untuk merespon permasalahan tersebut". ${ }^{17}$

Alasan pernyataan Ketua dan Komisi Fatwa MUI NTB yang tidak mempermasalahkan kebijakan pendewasaan usia pernikahan di NTB, karena adanya mudharat yang ditimbulkan akibat pernikahan usia dini, diperkuat dengan hasil kajian Komisi Penelitian dan Pengkajian MUI NTB, bahwa perlu ada intervensi pemerintah dalam mengatur perilaku kehidupan masyarakat yang kurang baik, akibat referensi hidup masyarakat yang lebih cenderung hanya berpatokan pada nilai ajaran agama dan budaya, namun terkadang pemahamannya yang tidak terlalu utuh dan sempurna, sulit dilakukan pembaharuan jika hanya mengandalkan pendekatan kultural, seperti melalui mimbar-mimbar dakwah. ${ }^{18}$

Pandangan MUI NTB tentang pembatasan usia pernikahan di atas juga diperkuat dengan ayat-ayat al-Qura'an maupun hadits yang menjadi rujukan sumber hukum Islam, yang tidak ada secara khusus menjelaskan tentang standar usia sebagai syarat bagi umat Islam untuk melangsungkan pernikahan pertamanya. Salah satu ayat al-Qur'an yang menjadi rujukan dalil tentang pernikahan ini yaitu firman Allah SW'T dalam Qs. Al-Nisa ayat 6:

Artinya:

Dan ujilah anak yatim itu sampai mereka cukup umur untuk kawin. Kemudian jika menurut pendapatmu mereka telah cerdas (pandai memelihara harta), maka serabkanlah kepada mereka harta-hartanya. dan janganlah kamu makan harta anak yatim lebih dari batas kepatutan dan (janganlah kamu) tergesa-gesa (membelanjakannya) sebelum mereka dewasa. barang siapa (di antara pemelihara itu) mampu, Maka hendaklah ia menahan diri (dari memakan harta anak yatim itu) dan barangsiapa yang miskin, maka boleblah ia makan barta itu menurut yang patut. Kemudian apabila kamu menyerabkan harta kepada mereka, Maka hendaklah kamu adakan saksi-saksi (tentang penyerahan itu) bagi mereka. dan cukuplah Allah sebagai Pengawas (atas persaksian itu). ${ }^{19}$

17 Mustamiuddin (Ketua Komisi Fatwa MUI NTB), Wawancara, 10 Maret 2018.

18 Komisi Penelitian dan Pengkajian MUI NTB, Peta Dakwah MUI NTB (Mataram, MUI NTB, 2017), 15.

19 DP3KB NTB, Buku Saku, 8. 
Berdasarkan ayat tersebut di atas, bahwa dalam agama Islam tidak pernah menentukan batas usia seseorang dipandang telah cukup matang untuk menikah. Dalam al-Qur'an surat al-Nisa ayat 6 hanya menyebutkan lafadz balaghun-nikah (baligh untuk menikah) disertai dengan lafadz rusyd (kecerdasan). ${ }^{20}$ Sedangkan al-Hadits yang menunjukkan tentang persyaratan usia bagi pasangan pernikahan, sebagaimana diriwayatkan Bukhori, yaitu:

Artinya:

Hai kaum muda, jika di antara kamu sudah ada kesiapan untuk menikah, maka nikablah, karena itu akan menundukkan pandangan matamu dan lebih dapat menjaga alat reproduksinya (HR. Bukhori). ${ }^{21}$

Hadits di atas menjelaskan bahwa pernikahan sebagai pelaksanaan hukum keluarga Islam diberlakukan bagi yang sudah memasuki usia sebaga pemuda dengan syarat dia harus mampu untuk melakukannya (al-Baab), yaitu mampu untuk melakukan hubungan suami istri (jima'), mampu untuk membiayai kebutuhan pernikahan dan kelangsungan hidup keluarganya. Dengan kata lain kata al-Baah dimaknai sebagai kemampuan pemuda yang meliputi aspek sebagai berikut:

1. Kemampuan fisik, yang ditandai dengan adanya kesehatan yang memadai, sehingga kedua belah pihak mampu melaksanakan semua fungsi dan tanggung jawab keluarga dengan baik.

2. Kemampuan finansial, yang terkait erat dengan faktor ekonomi, yang berarti bahwa para pasangan yang ingin melangsungkan pernikahan harus mampu membiayai kebutuhan hidup kelangsungan keluarganya.

3. Kemampuan mental, yang ditandai dengan kedewasaan atau kebijaksanaan dalam mengambil keputusan ketika berhadapan dengan problematika kehidupan keluarga, karena bersatunya dua belah pihak yang berlatar belakang berbeda, membutuhkan penyesuaian diri untuk menciptakan keharmonisan.

4. Kemampuan spiritual, kedua belah pihak harus memiliki pemahaman keagamaan yang lebih kuat, agar mampu memaknai secara lebih utuh hakikat pernikahan yang dia langsungkan, terutama dalam membina keluarga yang sakinah, mawaddah, warahmah.

Persetujuan MUI NTB terhadap pemberlakuan kebijakan pendewasaan usia pernikahan di NTB oleh Pemerintah Provinsi NTB, yang dimaksudkan untuk menjaga keutuhan sebuah keluarga (menekan tingkat perceraian) dan menjaga kualitas IPM NTB yang lebih baik, menjelaskan bahwa menurut fatwa MUI NTB

20 Setyanto, "Hukum Islam," 180.

21 DP3KB NTB, Buku Saku, 8. 
pernikahan bukan perbuatan untuk dimain-mainkan untuk suatu kesenangan biologis atau kesenangan pribadi semata, tetapi merupakan ajaran agama untuk kemaslahatan umat, sehingga harus dilakukan dengan ketentuan yang telah ditetapkan, baik secara agama maupun aturan pemerintah. Dengan kata lain, fatwa MUI NTB ini sejalan dengan pandangan Yanggo, bahwa pernikahan merupakan suatu ikatan suci dalam rangka membangun kelangsungan generasi atau keturunan umat manusia. ${ }^{22}$

Dalam perspektif hukum Islam, pernikahan juga tidak sekedar bertujuan untuk menyalurkan kebutuhan biologis secara sah, baik menurut aturan hukum, tetapi juga dalam rangka membina dan menjaga keharmonisan dan keutuhan bangunan rumah tangga. Hal ini bertolak dari dalil yang dijelaskan dalam Qs. Al-Rum ayat 21:

\section{Artinya:}

Dan di antara tanda-tanda kekuasaan-Nya ialah Dia menciptakan untukmu istriistri dari jenismu sendiri, supaya kamu cenderung dan merasa tenteram kepadanya, dan dijadikan-Nya di antaramu rasa kasib dan sayang. Sesunggubnya pada demikian itu benar-benar terdapat tanda-tanda bagi kaum yang berpikir. ${ }^{23}$

Berdasarkan ayat di atas, pernikahan sebagai salah satu praktik hukum keluarga Islam yang dilangsungkan masyarakat, merupakanjembatanatau media bagiumatIslam untuk membentuk sebuah keluarga yang sejahtera dalam menjalani kehidupannya, dengan kondisi idealnya yaitu sakinah (penuh kedamaian, ketenangan, ketentraman, dan keamanan), mawaddah (saling memiliki rasa cinta, kasih sayang, dan penuh harapan), dan rahmah (penuh kebaikan dan rahmat), yang akan tercapai jika suami istri menjalani hidupnya sesuai dengan prinsip keimanan, saling menyayangi satu sama lain, menerima kekurangan masing-masing pasangan, dan saling melengkapi. ${ }^{24}$

Ketika pernikahan yang dilangsungkan masyarakat tidak lagi memberikan dampak positif bagi kehidupan keluarga dan masyarakat, seperti mengganggu kualitas generasi masa depan masyarakat dan bangsa, mengganggu tatanan sosial masyarakat dan keluarga, maka meskipun pernikahan merupakan hak individu, sudah menjadi tanggung jawab negara atau pemerintah untuk mencegahnya, dalam rangka menjamin kehidupan masyarakat yang lebih baik. Jika pernikahan dalam usia dini menimbulkan efek negatif, seperti digambarkan dalam kasus yang terjadi di NTB, jelas ini bertentangan dengan tujuan pernikahan dalam Islam, sehingga perlu dicarikan solusinya. Pandangan MUI NTB yang tidak mempermasalahkan pembatasan usia pernikahan, seperti diatur dalam Surat Edaran Gubernur NTB, minimal 21 tahun, sebagai upaya mencegah efek negatif yang lebih besar daripada

22 Chuzaimah T. Yanggo, Problematika Hukum Islam Kontemporer (Jakarta: Pustaka Firdaus, t.t), 67.

23 DP3KB NTB, Buku Saku, 10.

24 DP3KB NTB, Buku Saku, 34. 
efek positif, dapat menjadi rujukan bagi praktik pernikahan di tengah masyarakat, untuk menghindari hilangnya tujuan pernikahan dalam konteks hukum keluarga Islam, karena jika proses pernikahan tersebut tidak memenuhi berbagai ketentuan yang telah ditetapkan, baik secara agama maupun negara, dapat menyebabkan tujuan ideal suatu pernikahan akan hilang.

Dalam Islam, pernikahan adalah kesepakatan antara seorang pria dan seorang wanita untuk membentuk sebuah keluarga dan guna meneruskan generasi. Berdasarkan tujuan ini, guna mewujudkan keluarga yang bahagia dan generasi yang berkualitas, pelaksanaan pernikahan membutuhkan beberapa persyaratan, di antaranya kematangan emosional, kesiapan fisik bagi perempuan, dan kemampuan ekonomi. ${ }^{25}$ Sedangkan dalam ilmu kedokteran, menurut Sumarjati, kematangan fisik seorang perempuan terjadi pada usia 20 tahun, karena pada usia inilah alat produksi perempuan akan bekerja secara maksimal, sehingga resiko kematian bayi dan ibu lebih rendah daripada perempuan yang menikah di bawah usia tersebut. ${ }^{26} \mathrm{Hal}$ ini berarti bahwa salah satu faktor yang dapat menyebabkan tidak terwujudnya tujuan dan cita-cita ideal dari suatu ikatan suci yang dibangun masyarakat melalui penikahan yaitu ketika pasangan suami-istri tersebut tidak cukup matang dalam usia.

\section{Pandangan MUI}

Pandangan MUI NTB yang tidak menyalahkan intervensi Pemerintah provinsi NTB melalui SE Gubernur yang mengatur tentang batas usia minimal menjadi 21 tahun syarat usia menikah bagi masyarakat NTB, termasuk yang beragama Islam, memang logis, karena dalam Islam, pernikahan memiliki makna religius yang sangat tinggi nilainya, karena pernikahan bukan hanya sekedar tindakan hukum yang berkaitan dengan sah tidaknya, tetapi juga merupakan suatu pertalian hubungan yang sah antara seorang laki-laki dengan seorang perempuan untuk hidup bersama sehingga terjadi hubungan suami-istri dengan tujuan membentuk keluarga dan menjaga keturunan serta mencegah perzinahan dan menjaga ketentraman jiwa dan keluarganya. Namun, ketika dampak pernikahan menyimpang dari tujuannya akibat perilaku masyarakat (mudlaratnya lebih besar dari manfaatnya), sebagaimana yang resiko pernikahan usia dini, kehadiran pemerintah dengan kebijakannya untuk mencegah perilaku sosial masyarakat menjadi suatu tuntutan, ketika masyarakat tidak dapat mengatasi problematika kehidupannya secara mandiri.

25 Ropida dkk, "Pilihan Rasional," 2016.

26 Hawari dkk, Persiapan Menuju, 11. 
Selanjutnya, terkait dengan persetujuan MUI NTB terhadap pemberlakuan kebijakan pendewasaan usia pernikahan di NTB, ada aspek yang menjadi dasarnya, yaitu:

1. Aspek hukum. Persetujuan MUI NTB berdasarkan aspek hukum ini terlihat dari tidak adanya memang ketentuan yang secara eksplisit tentang batas usia yang dikategorikan balig dan berakal sebagai syarat penikahan di dalam al-Qur'an dan al-Hadits. Sehingga MUI NTB menganggap tidak ada salahnya dibuat ketentuan syarat minimal usia untuk menikah bagi masyarakat.

2. Aspek politik. Persetujuan MUI NTB tersebut dibangun dengan alasan bahwa dalam konteks hidup berbangsa dan bernegara, harus mendukung kebijakan yang dibuat negara, karena dialah yang memiliki otoritas untuk membuat kebijakan, dan menjadi kewajiban setiap warga negara, baik secara individu maupun organisasi untuk mendukung kebijakan yang dibuat negara.

3. Aspek sosial. Persetujuan MUI NTB terhadap kebijakan pendewasaan usia pernikahan atau pembatasan usia minimal menjadi 21 tahun untuk syarat pernikahan, karena kebijakan pendewsaan usia pernikahan tersebut dihajatkan untuk kemaslahatan hidup keluarga, masyarakat, maupun bangsa.

Sikap MUI NTB yang tidak menganggap salah tentang pembatasan usia pernikahan untuk pertama kalinya bagi masyarakat, tentu tidak melanggar ketentuan hukum Islam, karena batas usia yang pantas dan layak untuk melangsungkan pernikahan tidak ada penjelasan secara tegas dalam al-Qur'an dan al-Sunnah. Meskipun ada pendapat ulama yang mengatakan sah hukumnya pernikahan usia anak, bahkan pernah dilakukan Rasulullah SAW ketika menikahi Siti Aisyah pada usia 9 tahun, namun saat ini tidak bisa dibiarkan karena efek negatifnya yang lebih besar daripada efek positifnya. Untuk itulah, kehadiran law as social engenering sebagai kontrol sosial menjadi penting, dan tentunya mebutuhkan dukungan institusi keluarga, pendidikan, moral, dan agama. ${ }^{27}$

Sebagaimana diketahui, bahwa tidak semua aspek kehidupan manusia yang terkait dengan persoalan Hukum Keluarga Islam, yang diatur dan dijelaskan secara eksplisit dalam sumber-sumber hukum Islam. Dalam menghadapi masalah-masalah kehidupan sosial masyarakat Islam, terutama terkait dengan penetapan hukum yang tidak ada dalam sumber-sumber hukum Islam yang ada, salah satu lembaga fatwa Hukum Islam di Indonesia yang diberikan otoritas untuk menentukan hukum pada suatu persoalan hukum Islam adalah Majelis Ulama Indonesia (MUI). Lembaga fatwa Hukum Islam ini merupakan wadah yang mengorganisir keberadaan para

27 Setyanto, "Hukum Islam," 180. 
ulama, zuama, dan cendekiawan muslim Indonesia dalam rangka menyatukan pandangan, gerak, dan langkah-langkah umat Islam Indonesia dalam mewujudkan cita-cita bersama.

Pernyataan Komisi MUI NTB yang mendukung intervensi Pemerintah NTB yang mengatur batas usia pernikahan bagi masyarakat, secara tidak langsung memberikan fatwa tentang dibolehkannya membuat ketentuan batasan usia pernikahan bagi masyarakat. Sayangnya, fatwa MUI NTB ini belum diformalkan dalam bentuk Surat Keputusan tentang fatwa MUI NTB. Sedangkan dasar fatwa MUI NTB, yang membolehkan pembatasan usia pernikahan ini ada dua:

1. Aspek hukum, yaitu karena di dalam al-Qur'an dan Sunnah tidak ada penjelasan secara tegas tentang usia dibolehkannya menikah, sehingga ini menjadi ruang untuk menafsirkan secara fleksibel ketentuan kata baligh dan berakal dalam pendapat ulama tentang syarat pernikahan.

2. Aspek sosial, yaitu untuk kemaslahatan umat, karena seperti hasil kajian bahwa pernikahan usia anak yang terjadi di NTB, ternyata lebih membawa mudharat daripada manfaatnya. ${ }^{28}$

Jika memperhatikan dasar fatwa MUI NTB terhadap pemberlakuan kebijakan pendewasaan usia pernikahan di atas, bahwa metode penentuan hukum Islam yang digunakan MUI NTB lebih cenderung ke metode Istishlah, yaitu suatu upaya penetapan hukum yang didasarkan kermaslahatan atau kebaikan (mashlahah mursalab). ${ }^{29}$ Sedangkan mashlahah mursalah sebagai metode penentuan hukum Islam, yang mempertimbangkan adanya kemanfaatan yang mempunyai akses secara lebih luas untuk kepentingan yang tidak terbatas dan tidak terikat, merupakan kepentingan yang diputuskan bebas, namun tetap terikat dengan konsep syari'ah, karena syari'ah sendiri ditunjuk untuk memberikan kemanfaatan kepada masyarakat secara umum dan berfungsi untuk memberikan kemanfaatan dan mencegah kemudharatan.

Sedangkan ruang lingkup berlakunya mashlabah mursalab menurut Muhammad Abu Zahrah, dibagi tiga, yaitu:

Al-Mashlahah al-Daruriyyah, yaitu untuk kepentingan-kepentingan yang esensial dalam kehidupan, seperti untuk memelihara agama, memelihara jiwa, akal, keturunan, dan harta.

1. Al-Mashlahah al-Hajjaayah, yaitu untuk kepentingan-kepentingan esensial di bawah al-daruriyyah, namun diperlukan dalam kehidupan manusia, agar tidak mengalami kesukaran dan kesempitan, jika tidak terpenuhi tidak akan mengakibatkan

28 Mustamiuddin (Ketua Komisi Fatwa MUI NTB), Wawancara, 10 April 2018.

29 Khaerudin Nasution, "Metode Pembaharuan," 335. 
kerusakan kehidupan, tetapi hanya akan mengakibatkan kesukaran dan kesempitan.

2. Al-Mashlabah al-Tabsiniyyah, yaitu untuk kepentingan-kepentingan pelengkap, yang jika tidak terpenuhi tidak akan menimbulkan kesukaran dan kesempitan, karena ia tidak begitu membutuhkannya, tetapi hanya sebagai pelengkap atau hiasan hidup masyarakat. ${ }^{30}$

Fatwa MUI NTB tentang pemberlakuan kebijakan pendewasaan usia pernikahan yang dikeluarkan Gubernur NTB, jika dilihat dari aspek hukum merupakan bagian dari syari'at Islam, yang terkait dengan Hukum Keluarga Islam, dimana akan mempunyai dua implikasi dalam kehidupan ummat manusia. Pertama, sebagai acuan hukum positif, seperti yang tercermin dalam praktik peradilan atau quasi peradilan. Kedua, sebagai acuan dalam menentukan batasan tindakan umat Islam dalam mengahadapi suatu obyek atau peristiwa kehidupan, yang tercermin dalam lima kaedah Hukum Islam, yaitu wajib, sunnat, haram, makruh, dan mubah yang berbentuk ifta' atau fatwa untuk pedoman masyarakat umum. Untuk implikasi pertama, syariat Islam sudah mendapatkan legalitas, namun sifatnya terbatas dalam kewenangan Peradilan Agama (Mahkamah Syar'iyah) di Indonesia sampai ke tingkat banding di Pengadilan Tinggi Agama Provinsi, hingga tingkat kasasi di Mahkamah Agung. Sedangkan untuk implikasi kedua, yang menyangkut otoritas fatwa, belum mendapat pengakuan sebagai legalitas hukum yang diakui dalam kehidupan berbangsa dan bernegara. Fatwa tidak termasuk sebagai bagian dari hukum positif (ius constitutum), sehingga dalam penerapannya tidak dapat dipaksakan seperti praktik hukum positif pada umumnya. ${ }^{31}$

Namun demikian, meskipun fatwa MUI NTB terhadap pemberlakuan kebijakan pendewasaan usia pernikahan bukan sebagai hukum positif, keberadaan fatwa dalam menghadapi dinamika sosial masyarakat, memiliki kedudukan yang sangat strategis dan penting, terutama dalam menemukan jalan keluar atas masalah-masalah yang kontoversial yang terjadi di setiap zaman. Secara fungsional, fatwa memiliki fungsi tabyin, yaitu menjelaskan hukum yang merupakan regulasi praksis bagi masyarakat, terutama masyarakat yang memang mengharapkannya, dan fungsi tawjih, yaitu memberikan guidance (petunjuk) serta pencerahan kepada masyarakat luas tentang permasalahan agama yang bersifat kontemporer, ${ }^{32}$

Fatwa MUI NTB terhadap kasus pemberlakuan kebijakan pendewasaan usia pernikahan, dalam perspektif hukum Islam, merupakan bentuk fatwa bersifat

30 Saifullah Ma'shum dkk (terj.), Ushul Fiqih (Jakarta: Pustaka Firdaus, 2005), 426.

31 Rohadi Abdul Fatah, Analisis Fatwa Keagamaan (Jakarta: Bumi Aksara, 2006), 4.

32 Riadi, "Kedudukan Fatwa," 477. 
kasuistik, karena merupakan respon atas pertanyaan pada kasus tertentu. Berkaitan dengan kedudukan fatwa dalam kehidupan umat Islam, meskipun tidak mengikat secara hukum, namun fatwa tetap bersifat mengikat secara agama. Oleh karena itu, jika fatwa tersebut memang dilandasi dengan dalil-dalil yang jelas, kuat, dan benar, maka tidak ada alasan atau peluang bagi seorang muslim untuk menentangnya fatwa tersebut, karena bagian dari ijtihad untuk menyelesaikan permasalahan kehidupan umat Islam. ${ }^{33}$

Memang harus diakui, bahwa peran fatwa cukup strategis dalam memahamkan ajaran agama kepada umat Islam. Melalui kehadiran fatwa, masyarakat bisa mengetahui yang harus dilakukan. Apalagi dalam konteks model fatwa yang bersifat tematis. Di tengah dinamika perubahan sosial yang menimbulkan berbagai persoalan dalam kehidupan masyarakat, yang menyentuh hingga dimensi nilai-nilai hukum keagamaan yang tidak ada penjelasan secara tegas pada sumber-sumber hukum Islam yang telah ada, maka dalam situasi inilah keberadaan fatwa menjadi penengah antara masyarakat dan agama. Bahkan, masyarakat jauh lebih dekat kepada fatwa ketimbang agama itu sendiri. ${ }^{34}$

Di samping itu, dalam kasus pemberlakuan kebijakan pendewasaan usia pernikahan ini, karena kebijakan tersebut dihajatkan pemerintah untuk melindungi masyarakat, maka memang sudah menjadi kaharusan dalam penentuan fatwa MUI NTB mempertimbangkan aspek kemaslahatan bagi masyarakat. Karena metode mashlahah yang digunakan dalam pemberian fatwa dalam legislasi hukum Islam yang dewasa ini otoritasnya diberikan kepada MUI dalam konteks negara Indonesia, merupakan langkah untuk menghilangkan kesulitas dalam berbagai aspek kehidupan, terutama dalam masalah-masalah sosial kemasyarakatan. ${ }^{35}$

Untuk itu, untuk mengeluarkan fatwa pada masa sekarang perlu dilakukan melalui ijtihad kolektif, melibatkan berbagai hasil kajian yang terkait dengan sebabakibat dari tingginya jumlah masyarakat NTB yang melangsungkan pernikahan usia dini, dan dalam penyusunan fatwa tersebut, para mufti harus memegang teguh etika-etika berfatwa, yaitu: menjauhi otoritarianisme, mempertimbangkan tradisi mustafti, fatwa harus bersifat moderat, mengikuti bahasa hati, bukan hawa nafsu, mempermudah, tidak mempersulit. ${ }^{36}$ Dengan demikian, fatwa MUI dalam perspektif law as social engenering akan hadir sebagai instrumen bagi pembaharuan perilaku kahidupan masyarakat (social change), dan akan membawa kebaikan bagi kehidupan masyarakat secara umum (mashlahah mursalah), sebagimana cita-cita syari'ah.

33 Jaih Mubarak, Ijtihad Kemanusiaan (Bandung: Pustaka Bani Quraisy, 2005), 21.

34 Tahir, "Menimbang Etika Berfatwa," 393.

35 Al-Syatibi, Al-I'tishom (Beirut: Dar Al-Fikr, 1991), 115.

36 Tahir, "Menimbang Etika Berfatwa," 395. 


\section{PENUTUP}

Banyaknya praktik-praktik pernikahan yang dilakukan masyarakat yang masih tergolong usia anak-anak, mendorong pemerintah mengeluarkan ketentuan tentang pembatasan usia minimal masyarakat diberikan persetujuan untuk menikah. Pemberlakuan kebijakan pendewasaan usia pernikahan di NTB cukup efektif untuk menekan jumlah angka kasus pernikahan usia dini di NTB. Intervensi negara atau pemerintah dalam mengatur praktik hukum keluarga Islam melalui kebijakan pendewasaan usia pernikahan yang telah dilakukan Pemerintah Provinsi NTB, dalam pandangan MUI sebagai institusi yang memiliki otoritas menentukan hukum Islam, dibolehkan selama ada dasarnya, serta tujuannya untuk kemaslahatan orang banyak. Fatwa MUI yang membolehkan pemberlakuan kebijakan pendewasaan usia pernikahan berpijak pada metode Istishlah, atau mashlahah mursalah, karena tidak ada penjelasan secara tegas dalam al-Qur'an dan Sunnah tentang batasan usia sebagai syarat menikah bagi umat Islam.

\section{DAFTAR PUSTAKA}

Affan, Heyder, "Dikritik Putusan Mahkamah Konstitusi Soal Batas Usia Untuk Menikah", diakses 21 Februari 2017, bttp:/ / www.bbc.com.

Al-Syatibi, Al-I'tishom. Beirut: Dar Al-Fikr, 1991.

al-Zarqa, Mustafa Ahmad, al-Fiqh al-Islam fi Thaubihi al-Jadid: al-Madkhal al-Fiqih alAmm. Beirut: Dar al Fikr, t.t.

Amirudin, Zen, Ushul Fiqih. Yogyakarta: Teras, 2009.

Ansell, Cris and Alison Gash, "Collaborative Governance in Theory and Praktice", JPART 18, (2007): 547-571.

Anshori, Abdul Ghofur, Filsafat Hukum: Sejarah, Aliran, dan Pemaknaan. Yogyakarta: Gadjah Mada Press, 2005.

Asyad, "Metode Ijtihad Ormas Islam Indonesia," diakses, 4 Desember 2017, http:/ / kangasyad.blogspot.com.

BKKBN, "Rapat Koordinasi Revitalisasi Fungsi Keluarga Antara BKKBN Pusat Dengan Mitra”, Suara NTB, 29 Maret 2018.

BPS NTB, NTB Dalam Angka 2016. Mataram: BPS NTB, 2017. 
Buzama, Khoiruddin, "Pemberlakuan Teori-teori Hukum Islam di Indonesia," AlAdalah 10, no. 4 (Juli 2012): 467-472.

Darmodihirjo, Darji dan Sidharta, Pokok-Pokok Filsafat Hukum. Jakarta: Gramedia Pustaka Utama, 1995.

Devi, Putu Santy, Perkawinan Usia Dini dampak Dari Perkawinan Massal: Kajian Struktur Sosial di Desa Pengotan Kebupaten Bangli. Skirpsi. Denpasar: Fisip UNUD, 2014.

Dirksen, Anak Agung Ngurah Gde, "Pengantar Ilmu Hukum”, Diktat. Denpasar: Fakultas Hukum Universitas Udayana, 2009.

Disbudpar, Statistik Kebudayaan dan Pariwisata Provinsi NTB 2016. Mataram: Disbudpar NTB, 2017.

Djasmani, H. Yacob, "Hukum Sebagai Alat Rekayasa Sosial Dalam Praktik Berhukum di Indonesia," MMH 40, no. 3 (Juli 2011): 365-374.

DP3KB, Buku Saku Pendewasaan Usia Perkawinan. Mataram: DP3KB NTB, 2017.

DP3KB, Bunga Rampai Praktik-Praktik Terbaik Pencegahan Pernikahan Usia Dini di NTB. Mataram: DP3KB NTB, 2017.

Fatah, Rohadi Abdul, Analisis Fatwa Keagamaan. Jakarta: Bumi Aksara, 2006.

Gray, Christoper Berry (ed), The Philosophy of Law an Encyclopedia. New York: Garland Publishing, 1999.

Gunarsyah, Singgih dan Singgih Yulia, Psikologi Praktik Anak Remaja dan Keluarga. Jakarta: Gunung Mulia, 1991.

Hawari, Dadang dkk, Persiapan Menuju Perkawinan Yang Lestari. Jakarta: Pustaka Antara, 1991.

Hidayat, Arief, "MK Tolak Naikkan Batas Usia Minimal Untuk Menikah", diakses 21 Februari 2017, bttp:/ / wmw.bbc.com.

Hidayat, Rachmat Taufik dkk., Almanak Alam Islami. Jakarta: Pustaka Jaya, 2000.

Hoker, MB., Islam Mą̧ab Indonesia: Fatwa-Fatwa dan Perubahan Sosial. Jakarta: Teraju, 2003.

Indonesia Legal Brief, "Kasus Perkawinan Anak di Indonesia Tertinggi se-Asia Pasifik," diakses 4 Maret 2017, bttp:/ / www.bukumonline.com.

Ishak, Ajub, "Ciri-Ciri Pendekatan Sosiologi dan Sejarah Dalam Mengkaji Hukum Islam," Al-Mizan 9, no. 1 (Juni 2013), 72-84. 
Komisi Penelitian dan Pengkajian MUI NTB, Peta Dakwah MUI NTB. Mataram, MUI NTB, 2017.

Laksana, Nuring Septyasa, "Bentuk-Bentuk Partisipasi Masyarakat Desa Dalam Program Desa Siaga Di Desa Bandung Kecamatan Playen Kabupaten Gunung Kidul Yogyakrta”, JAKP 23, no. 03 (Desember 2013): 1-15.

Lili, Rasjidi dan Ira Thania Rasjidi, Dasar-dasar Filsafat dan Teori Hukum. Bandung: Citra Aditya Bakti, 2007.

McDonald, S. and S. Young, "Cross-Sector Collaboration Shaping Corporate Social Responsibility Best Practice Within Mining Industry", Journal of Cleaner Production 37, (2012), 54-67.

Mubarak, Jaih, Ijtihad Kemanusiaan. Bandung: Pustaka Bani Quraisy, 2005.

Munawaroh, Siti, "Studi Terhadap Pernikahan Usia Dini di Kecamatan Seberang Hulu I Kota Palembang Ditinjau dari Hukum Islam," Intelektualita 5, no. 1 (Juni 2016): 35-44.

Nasution, Khaerudin, "Metode Pembaharuan Hukum Keluarga Islam Kontemporer," UNISLA 30, no. 66 (Desember 2007), 329-341.

Nasution, Khoiruddin, Pengantar Dan Pemikiran Hukum Keluarga (Perdata) Islam Indonesia. Yogyakarta: ACAdeMIA dan TAZZAFA, 2010.

Novita, Asti Amelia, "Collaborative Governance dan Pengelolaan Lingkungan Hidup di Kawasan Pertimbangan”, JIAP 4, no. 1 (Maret 2018): 27-35.

Nugroho, Riant, Public Policy: Dinamika Kebijakan, Analisis Kebijakan, Manajemen Kebijakan. Jakarta: Alex Media, 2012.

Nurhayati, "Pendewasaan Usia Pernikahan Menuju Genre 2025". Makalah, disampaikan dalam Kegiatan Desa Binaan UIN Mataram di Desa Sigerongan, 28 Agustus 2017.

Praja, Juhaya S., Filsafat Hukum Islam. Bandung: LPPM UIN Bandung, 1995.

Racmat Taufik Hidayat dkk., Almanak Alam Islami. Jakarta: Pustaka Jaya, 2000.

Rahardjo, Satjipto, Ilmu Hukum. Bandung: Citra Aditya Bakti, 2006.

Rasjidi, Lili dan Ira Thania Rasjidi, Dasar-dasar Filsafat dan Teori Hukum. Bandung: Citra Aditya Bakti, 2007.

Rasjidi, Lili dan Ira Thania Rasjidi, Pengantar Filsafat Hukum. Bandung: Mandar Maju, 2002. 
Riadi, M. Erfan, "Kedudukan Fatwa Ditinjau Dari Hukum Islam dan Hukum Positif", Ulumuddin 6, no. 6 (Desember 2010): 468-477.

Rifa’i, Moh. dkk, Terjemah Khulasah Kifayatul Akbyar. Semarang: Toha Putra, 1978.

Rifiani, Dwi, "Pernikahan Dini Dalam Perspektif Hukum Islam", de Jure 3, no. 2 (Desember 2017): 125-134..

Ropida dkk, "Pilihan Rasional Perempuan Menikah di Usia Dini", Jurnal Ilmiah Sosisologi 1, no. 1 (Juni 2016): 93-106.

Setiyanto, Danu Aris, "Hukum Islam Sebagai Rekayasa Sosial dan Implikasinya Dalam Undang-Undang Perkawinan di Indonesia," Ijtihad 17, no. 2 (Desember 2017): 175-189.

Sirtullaiali, "Sehari 40 Pasutri Di Ambang Perceraian," Lombok Post, 4 November 2016.

Sirtullaili, “Setengah Warga NTB Merarik Kodek," Lombok Post, 27 Maret 2015.

Soekanto, Soerjono, Pokok-Pokok Sosiologi Hukum. Jakarta: RajaGrafindo Persada, 2013.

Sonata, Depri Liber, "Metode Penelitian Hukum Normatif dan Empiris: Karakteristik Metode Penelitian Hukum," Fiat Justisia 8, no. 1 (Maret 2014): 15-35.

Sudarsono, Pokok-Pokok Hukum Islam. Jakarta: Rineka Cipta, 2001.

Suhadi, "Pernikahan Dini, Perceraian, dan Pernikahan Ulang: Sebuah Telaah Dalam Perspektif Sosiologi”, Komunitas 4, no. 2 (Desember 2012): 168-177.

Suherman, Gatot, "Fiqh Mazhab Indonesia: Konsep dan Aplikasi Pemikiran Hasbi as-Shiddiqi Untuk Konteks Islam Rahmat li Indonesia," AL-Mawarid 11, no. 1 (Agustus 2010), 112-127.

Tahir, Masnun, "Menimbang Etika Berfatwa Dalam Pemikiran Hukum Islam", Ulumuddin 5, no. 3 (Desember 2009): 391-398.

Tim Komisi Penelitian, Pengkajian, dan Dakwah MUI NTB, Peta Dakwah Majelis Ulama Indonesia NTB. Mataram: MUI NTB, 2018.

UNICEF, "Indonesia Berada Pada Urutan Ketujuh Pernikahan Anak", Running Title iNews TV, 3 November 2017.

UU No. 1 Tahun 1974 tentang Perkawinan dan UU No. 23 Tahun 2002 tentang Perlindungan Anak. 
UU Nomor 10 Tahun 2004 tentang Pembentukan Peraturan Perundang-Undangan RI.

Wignjosoebroto, Soetandyo, Dari Hukum Kolonial ke Hukum Nasional: Dinamika Sosial Politik dan Perkembangan Hukum di Indonesia. Jakarta: Rajawali Press, 1994..

Yanggo, Chuzaimah T., Problematika Hukum Islam Kontemporer. Jakarta: Pustaka Firdaus, t.t.

Yusnadi, Menuju Fiqh Keluarga Progresif. Jakarta: Kaukaba, 2015. 